\title{
CREATIVITY - MODERN REQUIREMENT FOR FOOTBALL TRAINING
}

\author{
H. Duda ${ }^{1}$, henryk.duda@awf.krakow.pl, ORCID: 0000-0002-0131-5456, \\ V.V.Khramov², khramov@grsu.by, ORCID: 0000-0001-5727-7877 \\ ${ }^{1}$ University of Physical Education, Krakow, Poland, \\ ${ }^{2}$ State University of Grodno, Grodno, Belarus
}

\begin{abstract}
Aim. The article deals with justifying creative trainings for football players. Materials and methods. The article is based on the study and logical analysis of psychological, pedagogical and methodical literature; synthesis of the advanced experience in the theory and practice of team sports training; synthesis of concepts and theoretical points. Results. The peculiarity of competitions in sports games is that the player should know what exactly is to be done in a given situation and be able to perform necessary actions in compliance with the targets. The efficiency of actions during the game is determined by the level of mental preparedness and special knowledge. Motor coordination only implements the action plan. This indicates the need to enhance the role of creative training in the structure of sports preparation. The intellectual component of training activities consists of the interaction between motor and mental abilities, the development of decision-making skills based on a systematic analysis of game situations, information processing, motor planning. Creative training is aimed at the development of mental abilities (perception, analysis, synthesis, decision-making). This implies such a pedagogical activity, which improves player's mental abilities and provides the player with knowledge about actions in a given situation. Conclusion. Modern methods of football training should be developed with the focus on its intellectual component. Creativity is aimed at preparing an athlete to achieve an advantage in a game situation based on the most effective application of physical abilities and theoretical provisions.
\end{abstract}

Keywords: training of football players, intellectual preparation, creative training, training.

Introduction. Analysis of the articles, dedicated to the improvement of football training, reveals that in recent years authors have focused their attention on the intellectual component of sports preparation and one of its elements - creative training. This issue is widely discussed in the Western European theory of sports training: creative training [12], the Coerver method [2], Teaching Games for Understanding [11], Life Kinetics method [5]. Further development in this area is regarded to be of a practical value as the efficiency of competitions in sports games depends on a player's ability to quickly and efficiently solve various situational problems. Therefore, one of the main aims of player's preparation is to acquire creative actions, which contribute to achieving an advantage during the game.

Aim. The article deals with justifying creative trainings for football players.

Materials and methods. The article is based on the study and logical analysis of psychological, pedagogical and methodical literature; synthesis of the advanced experience in the theory and practice of team sports training; synthesis of concepts and theoretical points.

Results. Taking into account the peculiari- ties of intellectual preparation, it is necessary to point out the content of a sports game. J. Mandigo, J. Butler, T. Hopper [6] wrote that 'when learning the game, we should teach the game, but not how to play it'. This seems quite contradictory, but the statement itself points our attention to the concept of efficiency in the conditions of a game environment. This concept points at the main sense of sports games - the player should know what exactly is to be done and how this must be done.

Intellectualization of game activities is the base of their efficiency. This is proved by the statement made by R. Panfil [9, p. 73]: A sports game is a situation of contradictory interests, where the participants, consciously or unconsciously, choose the targets and means of their achievement depending on present opportunities and situational actions. The main target of a sports game is to demonstrate the advantage over a rival in compliance with the established rules. This can be done by achieving intermediary targets in offensive and defensive actions.

A detailed analysis of football as a game reveals that situational actions (individual and group) are performed in compliance with the 
main target, which can be achieved using intellectual, motor, and physical abilities. Therefore, player's actions are determined by the situational component and present abilities. Z. Naglak [7] writes that situational potential includes the circumstances around the player in the particular period of the game, while available potential includes player's present abilities.

Activity during the game is multivariate, therefore, its components can be presented as independent situations. There are simple, complex, undefined or risky situations (see Fig. 1). During the game, an athlete should perform actions to estimate the situation and make a decision regarding its development.

A complex and varying game content requires not only relevant motor coordination, but also mental abilities, which possess a reproductive character as they are based on the application of previously acquired knowledge. The association areas of the cerebral cortex provide the efficiency of actions during a game. They perform a fundamental function in the transition from reflexive behavior to conscious actions. Successful external (manipulative) activity (movements) is a final product preceded by internal processes. Therefore, internal processes determine the quality of external actions. The player, who wants to improve his efficiency in game situations, should be able to forecast the consequences of certain events (expectations). This means the ability to anticipate prospects and opportunities or to realize their absence. The ability to anticipate events mostly depend on the knowledge of how to act in various situations.

One more peculiarity of mental activity connected with player's efficiency is the ability to quickly perceive and accurately recognize events.
This process is called perception and is regarded as an active reception, analysis, and interpretation of sensory phenomena, by means of which the incoming information is processed using the knowledge about the world stored in memory [3, p. 90]. Special knowledge combined with the experience gained during competitions contribute to the improvement of specific perception. This allows acting efficiently in dynamic and constantly changing game situations. Z. Naglak [7] writes that without knowledge (information about actions) a player is deprived of 'materials' for mental processing. Perception is manifested in the quick reception, processing, and assessment of the information through sensory organs, especially vision and hearing [13]. Situation perception is based on mental abilities and closely connected to understanding, forecasting, assessment, and reflection.

In a dynamic situation of a game, a player strives to achieve the target, performing conscious actions by making decisions based on the information obtained from the playground and depending on the target and emotions experienced. This means that decisions can be either efficient or inefficient. If an athlete solves consciously tasks in accordance with the target, this implies that he knows what should be done and acts tactically. Such a player estimates many problems and various ways of their solution to make a choice, which allows him to achieve targeted results. Special knowledge is a base for the internal program of actions. The content of such a program consists of the roadmap of motor activity, which is manifested in external actions based on the analysis of events.

An athlete usually possesses the alternative solution of a movement task in relation to a certain game situation based on the programs in his

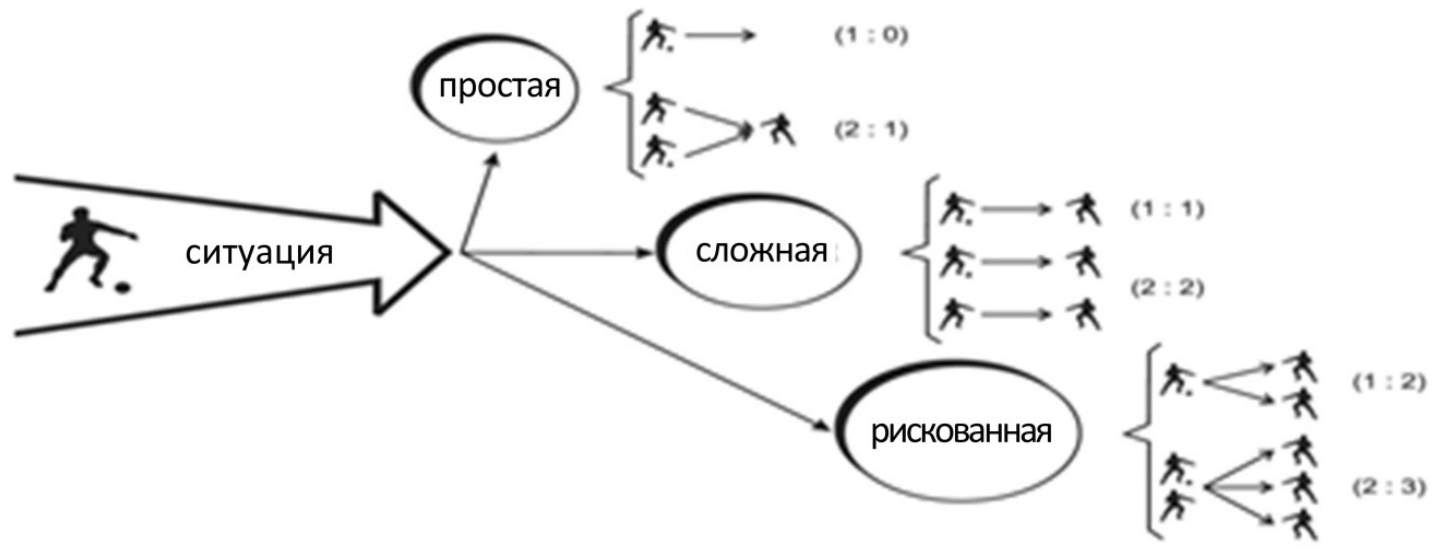

Fig. 1. Types of situations in football arising from the uncertainty of their outcome 


\section{Спортивная тренировка}

mind. The sooner the program of actions is formed as a result of mental activity, the better the player will demonstrate his abilities to use the methods of playing with and without the ball. External actions of the player have sense only when they are used to achieve a certain target. Therefore, internal and external actions are closely connected as this is a closed and interdependent psychomotor system [8].

This information proves that player's efficiency depends on the factors, which provide the motivation of his actions. That is why, studying should be based on mental development. Z. Naglak writes [7] that this method allows to teach movements when uncontrollable actions are substituted by purposeful and intellectual actions. This process is connected with movement perception (proprioception) and based on mental abilities. Mental abilities allow the player to acquire coach's attitudes for achieving certain goals on the basis of certain game situations. Such operations provide knowledge transferring regarding the conditions of effective performance, which allow the player to make decisions consciously. In the conditions of a sports game this means that:

- actions should be targeted (to whom when - how to throw the ball);

- actions should be conscious (the player knows what he is doing);

- actions should be flexible (diversity of simultaneous movement combinations).

The activization of mental processes provides the implementation of efficient and creative actions in sports games. R. Panfil [10, p. 59] writes that the concept of intellectualization in teaching movements should be treated as the substitution of uncontrolled behavior with the intellectual or mental control of an athlete. Therefore, this contributes to the conscious perception of motor activity and acquiring motor abilities with the help of mental abilities.

Player's efficiency is influenced by all the factors connected with decision-making: the systematical analysis of game situations, information processing, movement planning. These parameters are the main concepts of intellectualization and determine the basis for creative behavior during the game.

M. Kravchinsky [4] writes that there is no doubt about a direct link between motor abilities and cognitive processes. C. Alain and C. Sarrazin [1] prove this statement and write that decision- making is an important aspect of cognitive processes in sport. Therefore, the quality of one technical and tactical action equally depends on movement accuracy and the quality and speed of decision-making.

The intellectualization of training should be aimed at the formation of player's intellect. Intellectualization strives to enhance the link between motor and mental abilities in compliance with the phenomenon of internal synergy. Therefore, the effects of intellectualization should manifest in acquiring intellectual preparedness.

Conclusion. The main condition of acquiring player's rationality and efficiency in a certain situation is the intellectual activity, which is based on the knowledge about goal achievement. The trainings developed on the basis of creative learning should be directed at the improvement of mental abilities (perception, analysis, synthesis, decision making) and development of special knowledge. This implies such a pedagogical activity, which provides the player with the knowledge about actions in certain game conditions and improves his creativity. Creativity in learning allows athletes to achieve advantage in a game situation based on the most effective application of physical abilities and technical preparedness.

\section{References}

1. Alain C., Sarrazin C. Study of DecisionMaking in Squash Competition: a Computer Simulation Approach. Canadian Journal of Sport Sciences, 1990, no. 15, pp. 193-200.

2. Coerver Coaching. Available at: https:// playgreatsoccer.com (accessed 03.10.2018).

3. Grabowska A., Budohowska W. Procesy Percepcji. Psychologia Gólna. Warszawa, 1995, pp. 86-110.

4. Krawczyński M. Komunikacja w Dynamice Grupy Sportowej na Przykładzie Zespołu Piłki Nożnej. Rozprawy Naukowe Akademii Wychowania Fizycznego we Wroctawiu, 2012, vol. 37, pp. 11-15.

5. Lutz H. Besser Fußball Spielen mit Life Kinetik: Das Sensationelle Gehirn- und Bewegungstraining. Blv Verlag Leer, 2010. 144 p.

6. Mandigo J., Butler J., Hopper T. What is Teaching Games for Understanding? A Canadian Perspective. Physical \& Health Education Journal, 2007, no. 73 (2), pp. 14-20.

7. Naglak Z. Teoria Wielopodmiotowej Gry z Piłką Wśród Nauk o Sporcie. Rozprawy Nau- 
kowe Akademii Wychowania Fizycznego we Wrockawiu, 2011, no. 32, pp. 5-10.

8. Nitsch J.R. The Organization of Motor Behaviour: An Action - Theoretical Perspective. Movement and Sport. Psychological Foundations and Effects, 1994, vol. 2, pp. 3-21.

9. Panfil R. Prakseologia Gier Sportowych. Wrocław: Studia i Monografie, 2006. 188 p.

10. Panfil R. Coaching Uzdolnionego Gracza. Wrocław: Akademia Umiejętności - Management \& Coaching, 2007. 122 p.
11. Pearson P., Webb P., McKeen K. Developing Cognitive Abilities Through Games: A Conundrum? Australian Journal of Gifted Education, 2008, no. 17 (1), pp. 30-37.

12. Seeder F., Fave L. Kreatives Fußballtraining: 350 Trainingsformen für Ambitionierte Leistungsstufen. Meyer \& Meyer Sport, 2017. $392 \mathrm{p}$.

13. Weineck J. Wie Verbessere ich Die Schnelligkeit. Fussbaltraining, 1994, no. 3, pp. 8-18.

Received 23 December 2018

\title{
КРЕАТИВНОЕ ОБУЧЕНИЕ - СОВРЕМЕННОЕ ТРЕБОВАНИЕ К ПОДГОТОВКЕ ФУТБОЛИСТА
}

\author{
Г. Дуда', В.В. Храмов ${ }^{2}$ \\ ${ }^{1}$ Академия фризического воспитания имени Бронислава Чеха, г. Краков, \\ Республика Польша,

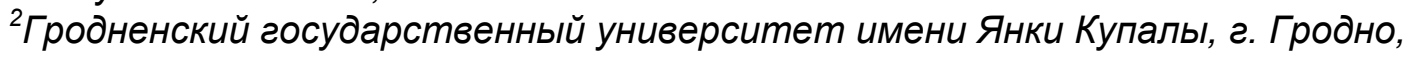 \\ Республика Беларусь
}

Цель. Обоснование целесообразности и направленности креативного обучения в подготовке футболистов. Материал и методы. Изучение и логико-содержательный анализ психолого-педагогической и методической литературы; обобщение передового опыта теории и практики по подготовке спортсменов в игровых видах спорта; синтез понятий и теоретических положений. Результаты. Особенность соревновательной деятельности в спортивных играх заключается в том, что игрок должен знать, что конкретно он должен делать в той или иной игровой ситуации, уметь это реализовать в соответствии с целевыми установками. Эффективность действий во время игры определяется уровнем сформированности мыслительных процессов и наличием специальных знаний. Двигательные координации лишь реализуют сформированный план действий. Это указывает на необходимость повышения роли креативного обучения в структуре спортивной подготовки футболиста. Интеллектуализация учебно-тренировочной деятельности заключается во взаимодействии двигательных и мыслительных способностей, развития умений принимать правильные решения на основе систематического обзора игровой ситуации, обработки информации, проектирования двигательной деятельности. Методы креативного обучения направлены на развитие мыслительных процессов (восприятие, анализ, синтез, принятие решений). Реализация данных установок на практике означает такую педагогическую деятельность, которая обеспечивает предоставление игроку знаний об операции в конкретных игровых ситуациях, развитие его мышления. Заключение. Современная методика подготовки футболистов должна развиваться по пути ее интеллектуализации. Креативность в методике обучения призвана подготовить спортсмена к достижению преимущества в игровой ситуации на основе наиболее эффективной реализации физических возможностей и технической основы действий.

Ключевые слова: подготовка футболистов, интеллектуальная подготовка, креативное обучение, учебно-тренировочный прочесс. 


\section{Спортивная тренировка}

Дуда Генрик, доктор наук о физической культуре, профессор, заведующий кафедрой спортивных и рекреационных игр, Академия физического воспитания имени Бронислава Чеха. Республика Польша, 1-571, г. Краков, Аллея Яна Павла II, 78. E-mail: henryk.duda@awf.krakow.pl, ORCID: 0000-0002-0131-5456.

Храмов Виталий Владимирович, доктор педагогических наук, доцент, заведующий кафедрой спортивных дисциплин, Гродненский государственный университет имени Янки Купалы. Республика Беларусь, 230023, г. Гродно, ул. Ожешко, 22. E-mail: khramov@grsu.by, ORCID: 0000-0001-5727-7877.

Поступила в редакцию 23 декабря 2018 2.

\section{ОБРАЗЕЦ ЦИТИРОВАНИЯ}

Duda, H. Creativity - Modern Requirement for Football Training / H. Duda, V.V. Khramov // Человек. Спорт. Медицина. - 2018. - Т. 18, № S. - С. 104-108. DOI: $10.14529 / \mathrm{hsm} 18 \mathrm{~s} 14$

\section{FOR CITATION}

Duda H., Khramov V.V. Creativity - Modern Requirement for Football Training. Human. Sport. Medicine, 2018, vol. 18, no. S, pp. 104-108. DOI: 10.14529/hsm18s14 